\title{
Information and source preferences of a student market in higher education
}

\author{
J. Bonnema, Department of Marketing and Communication Management, University \\ of Pretoria, Pretoria, South Africa \\ D.L.R. Van der Waldt, Department of Marketing and Communication Management, \\ University of Pretoria, Pretoria, South Africa
}

\begin{abstract}
Purpose - Marketing communication practitioners in higher education have not yet identified specific subgroups with similar characteristics within the prospective student (target) market, and do not always know which preferred sources learners consult when deciding on a tertiary institution for further or higher education. In addition, little is known about prospective students' information needs when deciding which institution to attend. As a result many tertiary institutions still use one message in one medium for all target markets. The aims of this paper are: to determine if sub-groups exist within the student recruitment market that need tailor made persuasive messages; to determine the preferred sources of information gathering for prospective students that influences their choice of tertiary institution; and to determine the information needs of prospective students that influence their decisions to select an institution of higher education.
\end{abstract}

Design/methodology/approach - A stratified random sample of 19 schools was drawn, from which a total of 716 successfully completed questionnaires were used to conduct factor and cluster analyses to determine information needs and source preferences of these respondents.

Findings - Ten factors under the VARCLUS procedure with high eigen values were grouped together with the following labels: university, college, employability aspects, course content, student experience, sporting aspects, financial aspects, direct sources, media sources and social sources. Five sub-groups clustered together with the K-means analysis, labelled: have lots, aspiring have lots, little direction and new lifers.

Research limitations/implications - A limited amount of literature is available on the current use of media and sources by the target market. Decisions on the choice of a tertiary institution for higher education are most probably influenced by socio-economic circumstances in a developing context, like South Africa.

Practical implications - An integrated and well co-ordinated media and message strategy for each of the various sub-groups should be specified for an IMC plan to be successful.

Originality/value - This is one of the few research articles on media and source 
preferences of potential students in the Cape Metropolitan. The cluster analysis revealed five clusters of sub-groups that have specific media and source needs to make the decision on furthering studies at tertiary level.

Keywords - Students, Recruitment, Higher education, South Africa, Information media, Consumer behaviour

Paper type - Research paper

\section{Introduction}

Since 2002, the educational landscape in South Africa has been undergoing immense changes, which have impacted on the perceptions and consumer behaviour of prospective students. Public tertiary institutions were merged during the period 2000-2004 to form new institutions, while a National Qualifications Framework (NQF) was implemented to regulate the programmes that should be provided by tertiary institutions. The result was the formation of a number of newly named institutions intended to meet the requirements of both the NQF and the specific needs of industry in the South African economy. Due to these changes, universities have been reorganised to meet the needs of different target markets in South Africa. These changes have been implemented with the intention of reaching government's objectives for equity, efficiency and development.

In the Cape Metropolitan, there are three Further Education and Training (FET) colleges and four universities. There were previously nine of the former and five of the latter. All the current institutions continue to serve the same geographical area as before, while continuing to recruit students from the same target market. The marketing implications of these mergers will entail a change in both the expectations of the target market and the relevant programmes on offer to them. As a result these new institutions have had to be re-branded, and new programmes being offered have had to be marketed accordingly.

Along with these changes in the educational landscape, marketing and marketing communication have also undergone significant changes. Up to the late 1980s, tertiary institutions had operated in a regulated environment, with guaranteed subsidies and the resulting students. Marketing was then viewed as a commercial concept that was relevant to commercial organisations but not to educational institutions (Mzimela, 2002:1-2). However, a top-down approach to communication is no longer relevant. Markets are now exposed to a "sphere of cross influences" from a number of different information sources (Edelman, 2004, p. 7). Marketers therefore need to review existing marketing communication practices, if they are to meet the new information needs of their markets. New technologies and media forms necessitate proper market segmentation and positioning by tertiary institutions if they wish to remain competitive. Within the Cape Metropolitan, prospective learners at tertiary institutions are drawn from a diverse range of communities with different demographic characteristics and, presumably, different information needs. 
In addition, the nature of South Africa's political history, and the resulting levels of the socio-economic circumstances of different South Africans have created a market place where student recruitment practitioners will have to produce marketing strategies that are both informed and heterogeneous (Mzimela, 2002, p. 2).

Tertiary institutions will have to address these heterogeneous target markets using communication strategies that take these differences into account. According to Goff $e t$ al. (2004, p. 796), communication messages that do not take into account the social and economic circumstances and consequent information requirements of the market may have little or no success.

A review of the literature shows that limited studies have been carried out to measure the high school learner's information needs regarding further study (Bruwer, 1996; Gaika, 2002; Imenda and Kongolo, 2002). Certain studies have focussed on the perceptions of students attending a university or a Technikon. Studies on Further Education and Training colleges have evaluated marketing strategies from the perspective of internal publics, but have not researched the actual information sources used by the market at whom the strategies are aimed.

In promoting the different types of institutions within the National Qualifications Framework (NQF), it would be of value to both university and college marketing communication practitioners to obtain information about the preferred sources and information needs, as well as the subgroups within their target markets, in order to create an integrated marketing communication (IMC) plan that would be specific to the Cape Metropolitan. Marketing communication practitioners in this industry have not yet identified specific subgroups with similar characteristics within the target market, and do not always know which preferred sources learners consult when deciding on a tertiary institution for further or higher education. In addition, little is known about prospective students' information needs when deciding which institution to attend.

\section{Problem statement}

Annually tertiary institutions compete with one another to effectively reach the approximately 86,000 prospective students with their persuasive messages. Little is known about the information needs and source preferences of prospective students in order to influence their decisions positively towards their choice on an institution of higher education.

\section{Research objectives}

1. To determine if sub-groups exist within the student recruitment market that needs tailor made persuasive messages.

2. To determine the preferred sources of information gathering for prospective students that influenced their choice of tertiary institution.

3. To determine the information needs of prospective students that influence their decisions to select an institution of higher education. 


\section{Method}

\subsection{Sample}

A stratified random sample of schools was drawn. This "is a probability sample that includes elements from each of the mutually exclusive strata within a population" (Cooper and Schindler, 2006, p. 448). The rationale for using this method of sampling were to increase the sample's efficiency, to provide adequate data for analyzing the various subpopulations and to enable different research methods to be used in different strata (Cooper and Schindler, 2006, p. 448). The Cape Metropolitan consists of six regional administrations, and is spread over a geographic area of $2454,7210 \mathrm{~km}^{2}$ (Municipal Demarcation Board (2006) (accessed 16 July 2006). In the 2001 Census, the population of Cape Town was counted at approximately 2.9 million people. The questionnaires were administered to learners with the assistance of a research assistant. Nineteen schools in the above areas were surveyed, and just over 920 surveys were administered.

The final number of satisfactorily completed questionnaires used consisted of 716 respondents $(n=716)$, of which 66 per cent were female. The majority of respondents spoke English (52 per cent), and the age spread of the respondents was primarily between 15 and 17 (78 per cent).

\subsection{Questionnaire}

As this questionnaire is based on a similar study done by staff and students at the University of Houston-Downtown, Texas (Goff et al., 2004), some of the factors contained in this questionnaire are similar or even exactly the same. However, owing to the vast differences between an American and a South African audience, the questions had to be updated to reflect more local responses. Mouton (2004, p. 102) points out that European and American instruments are not easily applied to a multi-cultural and multiethnic society like South Africa. These changes entailed referring to local educational institutions, using South African terminology referring to information sources (e.g. changing "college fairs" to "open days”), and referring to South African types of dwelling (e.g. terms such as informal housing, townships, rural areas etc.)

\subsection{Research procedure}

The questionnaire was pre-tested on three groups of learners who were representative of the survey population. In each instance, respondents were asked to give feedback on the content of the questionnaire and the clarity of the questions, and to highlight any difficulties experienced. After each pre-test, recommended changes were made before administering the survey to the next group. A total of 39 questionnaires were administered in the pre-testing of the instrument. 


\section{Results}

Cronbach's alpha was used to measure the internal consistency reliability of the constructs measured. The purpose of this exercise is to determine how successfully items that measure the same construct cede similar results. Generally, a Cronbach alpha value of 0.7 or more indicates that the questionnaire is internally consistent (Cooper and Schindler, 2006, pp. 237-8). However, Nunnally (1967) suggests that reliabilities of 0.5 and 0.6 will suffice for early stages of basic research (Smith, 1999, p. 113). As this study is exploratory in the South African context, a lower alpha value is therefore acceptable. Table I below reflects the alpha values for the respective factors.

\begin{tabular}{lclcr}
\hline Factor & Alpha value & Factor & Alpha value & \\
\cline { 1 - 3 } Employability & 0.59 & Financial aspects & 0.59 & \\
Student experience & 0.63 & Media sources & 0.86 & $\begin{array}{r}\text { Cronbach alpha's for the } \\
\text { identified factors }\end{array}$ \\
\hline
\end{tabular}

\subsection{Factor analysis}

The factor analysis was necessary to determine how preferred sources and information needs could be grouped together into main themes or categories within the target market. Ten factors emerged out of the factor analysis. The first two factors pertain to institution type, namely university and college/Technikon. Five factors emerged pertaining to information requirements namely, employability aspects, aspects of course content, overall student experience aspects, sporting aspects and financial aspects. Three factors emerged pertaining to preferred sources; they are social sources, direct sources and media sources.

The VARCLUS procedure was used for this part of the analysis. This procedure clusters the numeric variables in the data set, starting with one cluster and splitting the clusters until all the clusters have, at the most, one eigen value greater than one. After two clusters had been formed, no further clusters were found with an eigen value of 1 or approximately 1 . The sample data showed that there was no difference between the likelihood of students attending either a college or a Technikon, so these two types of institution were clustered together (Coetzee, 2006). Unlike the foregoing responses, which made no distinction between colleges and Technikon, learners showed that, in mind, they separated universities from other tertiary institutions.

The resulting ten factors with high eigen values were grouped under the following labelled factors:

1. University. This category includes the three universities in the Cape Metropolitan.

2. College. This includes universities of technology (previous Technikon), private colleges and public FET colleges.

3. Employability aspects. These are aspects of the institution that will enhance the chances of gaining employment after completion of studies. 
4. Aspects of course content. This includes the academic and practical components of the course.

5. Overall student experience aspects. These are whatever impacts the students' experience in travelling to the institution and spending time on campus.

6. Sporting aspects. These are the opportunities for and quality of sport at the institution.

7. Financial aspects. Costs involved in studying and the available assistance.

8. Direct sources. These are sources stemming directly from the institution.

9. Media sources. Print, electronic and outdoor media sources.

10. Social sources. Sources stemming from individuals with whom the learner may interact.

The factor analysis conducted showed that learners' preference for information sources could be divided into three categories. The following table (Table II) indicates which variables aligned according to their factor loading, thereby dividing into three information source factors. The three factors are in line with the information sources as determined by Goff et al. (2004), and are therefore named accordingly.

\begin{tabular}{|c|c|c|c|c|}
\hline & $\begin{array}{c}\text { Factor } 1 \\
\text { Media sources }\end{array}$ & $\begin{array}{c}\text { Factor } 2 \\
\text { Social sources }\end{array}$ & $\begin{array}{c}\text { Factor } 3 \\
\text { Direct sources }\end{array}$ & \\
\hline Web sites of institutions & 0.046 & -0.03 & 0.444 & \\
\hline Information brochures from institutions & 0.124 & -0.051 & 0.463 & \\
\hline Advertisements on billboards & 0.654 & 0.03 & 0.069 & \\
\hline Advertisements on television & 0.867 & -0.005 & -0.085 & \\
\hline Advertisements on radio & 0.877 & -0.034 & -0.098 & \\
\hline Advertisements in magazines & 0.662 & 0.042 & 0.053 & \\
\hline Advertisements in newspapers & 0.636 & 0.046 & 0.068 & \\
\hline Career exhibitions & -0.055 & 0.032 & 0.632 & \\
\hline Open days at institutions & -0.089 & -0.041 & 0.571 & \\
\hline Careers assessments & -0.016 & 0.179 & 0.452 & \\
\hline Free publications distributed at schools & 0.276 & 0.04 & 0.357 & \\
\hline Advice from a close friend & 0.039 & 0.542 & -0.015 & \\
\hline Advice from past or current students of institutions & 0.056 & 0.434 & 0.146 & \\
\hline Advice from school counsellors/guidance teachers & 0.188 & 0.381 & 0.08 & \\
\hline Advice from parents and guardians & -0.027 & 0.754 & -0.097 & \\
\hline Advice from family members (other than parents & & & & \\
\hline $\begin{array}{l}\text { and guardians) } \\
\text { Eigen value }\end{array}$ & -0.076 & 0.715 & -0.024 & $\begin{array}{r}\text { Table II. } \\
\text { Division of preferred }\end{array}$ \\
\hline $\begin{array}{l}\text { Eigen value } \\
\text { Percentage of variance explained }\end{array}$ & $\begin{array}{l}4.52 \\
242\end{array}$ & $\begin{array}{l}1.84 \\
8.57\end{array}$ & 7.14 & $\begin{array}{r}\text { Division of preferred } \\
\text { sources into categories }\end{array}$ \\
\hline Factor mean & 3.65 & 3.83 & 4.28 & $\begin{array}{l}\text { sources into categories } \\
\text { according to factor }\end{array}$ \\
\hline Factor standard deviation & 0.98 & 0.77 & 0.6 & loadings \\
\hline
\end{tabular}

The study shows that there are specific categories of information sources that each subgroup prefers to consult when seeking information about tertiary institutions. The study has also shown that media or advertising sources are not always the preferred source, but that social sources, word of mouth or direct sources from the institution are sometimes preferred. Table III indicates which variables aligned according to their factor loading, thereby dividing into five information needs factors.

Table III indicates that five specific categories of information needs are identified among the target market. As discussed above, each subgroup was found to have specific information needs that needed to be met in selecting a tertiary institution. 


\begin{tabular}{|c|c|c|c|c|c|}
\hline & $\begin{array}{l}\text { Factor } 1 \\
\text { Sporting aspects }\end{array}$ & $\begin{array}{c}\text { Factor } 2 \\
\text { Course content }\end{array}$ & $\begin{array}{c}\text { Factor } 3 \\
\text { Financial aspects }\end{array}$ & $\begin{array}{c}\text { Factor } 4 \\
\text { Overall student } \\
\text { experience }\end{array}$ & $\begin{array}{c}\text { Factor } 5 \\
\text { Employability } \\
\text { aspects }\end{array}$ \\
\hline A parent or guardian's preference & 0.047 & 0.091 & 0.092 & 0.009 & 0.163 \\
\hline $\begin{array}{l}\text { The institution's ability to place you in a job after } \\
\text { qualifying }\end{array}$ & 0.043 & -0.119 & -0.028 & -0.087 & 0.906 \\
\hline $\begin{array}{l}\text { graduation } \\
\text { grater }\end{array}$ & -0.029 & 0.039 & -0.015 & 0.057 & 0.486 \\
\hline The language of teaching of the institution & -0.054 & 0.264 & 0.068 & 0.113 & 0.04 \\
\hline The amount of practical content in the programme & 0.068 & 0.482 & -0.01 & 0.068 & 0.007 \\
\hline The amount of academic content in the programme & 0.073 & 0.826 & -0.08 & -0.132 & -0.029 \\
\hline The specific academic courses that are on offer & -0.056 & 0.492 & 0.058 & -0.049 & -0.012 \\
\hline Receiving personal attention in classes & 0.022 & 0.072 & 0.021 & 0.3 & 0.142 \\
\hline The distance of the institution from home & -0.002 & -0.01 & 0.268 & 0.202 & -0.01 \\
\hline The attractiveness of the campus (architecture, & & & & & \\
\hline buildings, landscape) & 0.06 & -0.057 & 0.038 & 0.393 & -0.024 \\
\hline The availability of hostel/residential facilities & 0.078 & -0.105 & 0 & 0.599 & 0.01 \\
\hline Student life at the institution & -0.04 & 0.052 & -0.047 & 0.617 & 0.032 \\
\hline Academic reputation of the institution & -0.083 & 0.289 & 0.007 & 0.22 & 0.131 \\
\hline The sporting excellence of the institution & 0.875 & 0.017 & 0.014 & 0.034 & 0.055 \\
\hline The sporting opportunities at the institution & 0.903 & 0.009 & 0.013 & 0.056 & -0.02 \\
\hline The cultural opportunities at the institution & 0.149 & 0.168 & 0 & 0.336 & -0.038 \\
\hline Safety on campus & -0.056 & 0.126 & 0.119 & 0.286 & 0.102 \\
\hline The cost of tuition at the institution & -0.06 & 0.02 & 1.057 & -0.121 & -0.067 \\
\hline $\begin{array}{l}\text { The availability of financial aid and scholarships at } \\
\text { the institution }\end{array}$ & & & & & \\
\hline $\begin{array}{l}\text { the institution } \\
\text { Eigen value }\end{array}$ & $\begin{array}{l}0.176 \\
3.58\end{array}$ & $\begin{array}{c}-0.016 \\
1.93\end{array}$ & $\begin{array}{l}0.389 \\
1.34\end{array}$ & $\begin{array}{l}0.016 \\
1.28\end{array}$ & $\begin{array}{l}0.124 \\
1.22\end{array}$ \\
\hline $\begin{array}{l}\text { Eigen value } \\
\text { Percentage of variance explained }\end{array}$ & 8.5 & 11.99 & 9.75 & 4.67 & 3.6 \\
\hline Factor mean & 3.35 & 4.11 & 4.26 & 3.68 & 4.46 \\
\hline Factor standard deviation & 1.36 & 0.64 & 0.89 & 0.7 & 0.76 \\
\hline
\end{tabular}

\subsection{Cluster analysis}

A cluster analysis identifies different groups or respondents who are similar to one another, but who differ from respondents in other groups. In this cluster analysis, Euclidean distances were measured using Ward's method of clustering, in which a dendogram (a graphical device) was used to identify possible clusters or subgroups. According to the dendogram, it was clear that five subgroups had been identified. The mean or average score for each respondent for each of the ten factors was calculated. Scores were standardised, putting the means scores for all ten factors on the same scale with the same variance (Coetzee, 2006). A K-means cluster analysis was then run, using Ward's method and Euclidean distances. Respondents were clustered into five subgroups in terms of standardised mean factor scores (Coetzee, 2006). The plot of the mean or average score for all respondents in each cluster gave an idea of the relevant importance of each factor to the respondents in each subgroup. The cluster analysis resulted in the emergence of five subgroups (see Figure 1). 


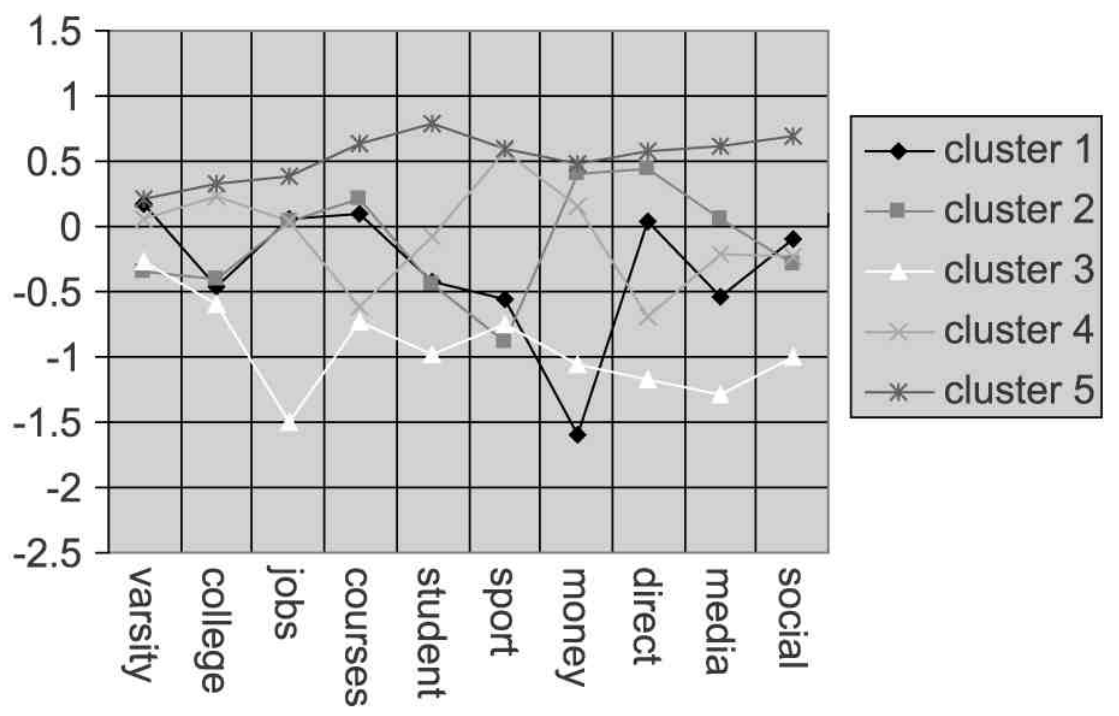

Figure $1 \mathrm{~K}$-means cluster analysis indicating the plot of means for each subgroup

The above K-means cluster analysis shows the particular preferences of each subgroup in terms of the ten factors derived. Five main information needs themes were derived from the factor analysis. In each instance, the theme gives an indication of respondents' beliefs and subsequent motivations, and therefore has to be considered in the responses of each subgroup. They are:

1. Jobs (employability aspects). Respondents who rate employability aspects highly consider the long-term implications of education. They consider their own ability to find a job after qualifying and whether the institution will help them find employment. This shows a concern for long-term need fulfilment and not just the short-term aspects of being a student. It may indicate the need to find a successful career, or to be self-sufficient.

2. Courses (aspects of course content). Respondents who rated course content highly consider the actual delivery of the programme and which factors they would regard as important in receiving an education. Academic aspects rate highly here, as well as the language of tuition and the practical course content.

3. Student life (overall student experience). Aspects of student life refer to the more personal aspects of an institution and how these impact the day-to-day experience of attending one. They include such considerations, as whether the student will find accommodation at the institution, whether there is easy transport to the institution and whether the campus is a safe place. Students who rate these factors highly are concerned with the environment in which they find themselves daily. They need to satisfy an aesthetic need, but are also are concerned about the logistics of attending an institution, and not only the long-term benefits of an education.

4. Sport (sporting aspects). It is important to note that sport implies also a number of social factors, such as winning, being part of a team, team social events and meeting people. All of these points contribute to social life on campus. They also 
contribute to the self-esteem that comes with being part of a team, especially a winning team.

5. Money (financial aspects). The financial aspects of attending an institution include the cost of the tuition and the availability of financial aid. Students who rate these aspects highly consider the practical implications of being able to afford an education.

6. Subgroups. Five main subgroups with unique characteristics were identified in the cluster analysis. The following is a description of the characteristics of each subgroup in terms of the specific demographics of the subgroup and their specific factor themes according to information requirements and preferred sources.

\section{Subgroup 1: “have lots”}

The members of this subgroup appear to come from wealthy homes where they have few material needs that cannot be met. As a result, they have been labelled the "have lots". This subgroup is made up of 83 respondents, most of whom are females (75 per cent). They are predominantly English speaking (70 per cent), aged between 15 and 17, and are mostly white or coloured. Most telling about this group is that they attend the most advantaged schools in the sample.

In the K-means cluster analysis, members of this subgroup overwhelmingly plan to attend university rather than college or Technikon. This correlates with findings of other studies in which students from a higher socio-economic background are more inclined to select universities rather than colleges or Technikon (Cosser and Du Toit, 2002; Davies and Guppy, 1997; Goff et al., 2004). Their main considerations in selecting an institution are factors relating to employability, and the specific course they wish to study. Student life and sporting factors rate lower, with aspects relating to the affordability of the institution rating extremely low. Regarding information sources, this subgroup will rely on direct sources, that is, information from the institution itself, but members do not value media sources. Social sources also rate highly.

They place no emphasis on the experience of being at university, but rather consider the long-term implications of what they study. It is clear that their material circumstances mean that money is not a significant consideration, and will not impact on what or where they study. Judging by the sources they prefer, they show that they are not intimidated by the institution, but believe that the institution's sources will be the most direct and honest in providing information. On the other hand they are sceptical of the advertising that may come from an institution, perhaps believing that it will be dressed up in marketing terms, and will not reflect the truth about the institution.

\section{Subgroup 2: “aspiring have lots”}

The members of subgroup 2 come from less affluent backgrounds than those of subgroup 1 but share the same aspirations. For this reason the subgroup is labelled "Aspiring have lots”. The members of subgroup 2 have their sights firmly set on being more like subgroup 1. Most aspects of their lives are quite similar to those of subgroup 1, but 
financial constraints still hold them back from being exactly like the first subgroup. Their parents have the same intentions for them.

This subgroup consists of 168 respondents, 77 per cent of whom are female. More than half (51 per cent) are coloured, but there are a high proportion of white respondents. The majority of respondents speak English at home, and are aged between 15 and 17, most being 17 already. Respondents in this group once again attend the more affluent schools in the survey as well as some more affordable schools. Noticeably, the most affluent school in the survey is under-represented in this subgroup. Fewer respondents in this subgroup attend girls-only schools.

The K-means analysis for subgroup 2 indicates that the respondents in this group plan to attend university, but quite possibly a Technikon or college, with the mean for this factor being very similar. In contrast to the previous subgroup, affordability is a primary consideration for this group when it comes to selecting a tertiary institution, and may be a prime reason for the close rating of both types of institutions. Notably, colleges and Technikon are more affordable than universities.

Following on the issue of affordability, members of this group look to specific courses and jobs when applying to an institution, rating the social aspects of sport and student life a lot lower. This shows that they are, in fact, very serious and ambitious, but have to deal with the initial reality of being able to afford their tuition. This appears to be a subgroup whose parents have made the necessary sacrifices for their children to get a good high school education, but may not have the requisite funds to pay for a tertiary education.

Members of this subgroup also trust direct sources from the institution when it comes to finding information about studying further. They do, however, rate media sources higher than social sources, indicating that they may be more trusting of media than of sources that they may know.

\section{Subgroup 3: "university lifers"}

Respondents in this subgroup show a greater interest in the social aspects of going to university than in any of the long-term benefits of such an education. They indicated in their responses that the university experience is their primary objective in attending such an institution, which earns them the label "university lifers".

This is the smallest subgroup, with 79 respondents. The group is made up of 63 per cent females and 36 per cent males, reflecting a very similar ratio to that of the survey respondents as a whole. Forty five percent of respondents in the group are coloured, and 32 per cent white. The majority (68 per cent) speak English at home. Respondents in this group clearly plan to attend a university rather than a college or Technikon. It seems that their main driver in choosing an institution lies with factors that will impact the student experience as a whole, such as the content of the course, the sporting aspects and aspects of student life. They are least concerned with affordability and the longer-term prospects of employability. Their main sources are social sources, particularly who will be able to 
give them a more honest report on what it is really like to attend a certain institution. This group is also less trusting of media sources, indicating some degree of media-savvy.

\section{Subgroup 4: "little direction"}

The members of this subgroup, in comparison with the other subgroups, show little knowledge of the opportunities open to them in terms of studying, coupled with very little motivation. This lack of direction as far as studying further and their futures in general are concerned has earned them the label of "little direction". This is the second largest subgroup, with 172 respondents. It consists of a considerably larger proportion of males than any other group. It is a largely African and Coloured group, with a relatively even spread of English, Afrikaans and Xhosa speakers, although the proportion of English speakers in relation to the group as a whole is lower. The majority of respondents are between 15 and 17, but a very high proportion of respondents are older than 18.

The 172 respondents in this subgroup make it the second largest of the subgroups. This subgroup can be described as a streetwise, masculine subgroup, whose members are older and more sceptical. They are, however, somewhat intimidated by the thought of studying further. The above K-means analysis shows that respondents in this subgroup are more likely to attend a college or Technikon than a university.

This group rates sport as the most important reason for attending an institution, followed by affordability. Course content rates the lowest. Perhaps this point gives the best indication about the group, as it implies that their knowledge of programmes and available courses is probably very limited. They rely on media and social sources to obtain more information about tertiary institutions, and are not inclined to consult direct sources. This may be because they have had limited exposure to institutions and find the thought of approaching an institution too daunting. Turning to social sources and to advertising (media sources) is both more familiar and less intimidating.

\section{Subgroup 5: “new lifers”}

The respondents in this subgroup indicate that their main aim is to escape the circumstances in which they currently find themselves, hoping that obtaining an education will be the key to this. For this reason they have been labelled the "new lifers". Consisting of 215 respondents, this is the largest subgroup in the study. Sixty nine percent of respondents are female and 31 per cent male, making it only a slightly more female subgroup than those in the study as a whole. The majority of respondents are Coloured or African, speaking mostly Afrikaans or Xhosa. Proportionately this subgroup has more Xhosa speakers than any other subgroup. Similarly, it has the highest proportion of Africans.

In terms of age, this group contains a large proportion of respondents over the age of 18. This is therefore a group that can be classified as being comprised of older African and coloured females. 
On the whole, these respondents believe that they will apply to a college or a Technikon rather than to a university. They rate aspects of student life as most important, followed by the course content and sporting aspects. The long-term aspects of employability do not feature highly amongst this group. It is possible that the top three factors here imply that students look for a safe haven during the day, and for better circumstances to go to. It is documented that life in disadvantaged circumstances in Cape Town's townships holds many hardships, which respondents may feel they can escape by attending an institution (Ramphele, 2002:12). Education is also seen as the only option for escaping the disadvantaged circumstances in which these students find themselves (Ramphele, 2002, p. 61).

These respondents look primarily to social sources for information on where to study. This correlates with subgroup 3, who also value aspects of student life, and who, like subgroup 5, prefer social sources of information. Respondents in this group also rate direct sources the lowest, indicating a similar aversion to that expressed by subgroup 4, and may find it intimidating to seek information directly from an institution. The following table (Table IV) gives a summary of the preferred information sources for each subgroup. It also lists each subgroup's preferred type of institution.

\begin{tabular}{|c|c|c|c|c|c|}
\hline & Subgroups & $\begin{array}{l}\text { Preferred } \\
\text { source } 1\end{array}$ & $\begin{array}{l}\text { Preferred } \\
\text { source } 2\end{array}$ & $\begin{array}{l}\text { Preferred } \\
\text { source } 3\end{array}$ & Preferred institution \\
\hline & $\begin{array}{l}\text { Subgroup } 1 \\
\text { Have lots }\end{array}$ & Direct & Social & Media & University \\
\hline & $\begin{array}{l}\text { Subgroup } 2 \\
\text { Aspiring have lots }\end{array}$ & Direct & Media & Social & $\begin{array}{l}\text { University, followed closely } \\
\text { by Technikon or College }\end{array}$ \\
\hline & $\begin{array}{l}\text { Subgroup } 3 \\
\text { University lifers }\end{array}$ & Social & Direct & Media & University \\
\hline $\begin{array}{l}\text { Table IV. } \\
\text { Information source }\end{array}$ & $\begin{array}{l}\text { Subgroup } 4 \\
\text { Little directions }\end{array}$ & Media & Social & Direct & College/Technikon \\
\hline $\begin{array}{l}\text { preference of each } \\
\text { subgroup }\end{array}$ & $\begin{array}{l}\text { Subgroup } 5 \\
\text { New lifers }\end{array}$ & Social & Media & Direct & College/Technikon \\
\hline
\end{tabular}

This gives an indication of the type of marketing communication the institution will need to use to attract members of each segment. Bearing in mind that, in many instances, tertiary institutions are in the process of redressing the past and hoping to attract historically disadvantaged students to have a student body in line with the greater population of the country, the information relating to each subgroup will be of use. A description of each subgroup's information needs is given in Table V. 


\begin{tabular}{|c|c|c|c|c|c|c|}
\hline & $\begin{array}{l}\text { Information } \\
\text { need } 1\end{array}$ & $\begin{array}{l}\text { Information } \\
\text { need } 2\end{array}$ & $\begin{array}{l}\text { Information } \\
\text { need } 3\end{array}$ & $\begin{array}{l}\text { Information } \\
\text { need } 4\end{array}$ & $\begin{array}{l}\text { Information } \\
\text { need } 5\end{array}$ & \\
\hline $\begin{array}{l}\text { Subgroup } 1 \\
\text { Have lots }\end{array}$ & Courses & Jobs & Student life & Sport & Money & \\
\hline $\begin{array}{l}\text { Subgroup } 2 \\
\text { Aspiring have lots }\end{array}$ & Money & Courses & Jobs & Student life & Sport & \\
\hline $\begin{array}{l}\text { Subgroup } 3 \\
\text { University lifers }\end{array}$ & Courses & Sport & Student Life & Money & Jobs & \\
\hline $\begin{array}{l}\text { Subgroup } 4 \\
\text { Little directions }\end{array}$ & Sport & Money & Jobs & Student life & Courses & Table V. \\
\hline $\begin{array}{l}\text { Subgroup } 5 \\
\text { New lifers }\end{array}$ & Student life & Courses & Sport & Money & Jobs & $\begin{array}{r}\text { Information needs of } \\
\text { each subgroup }\end{array}$ \\
\hline
\end{tabular}

It is clear that the respondents in each subgroup have particular preferences in terms of what information they need to make the decision. This gives institutions the tools with which to determine what information to use in marketing to specific groups.

\section{Conclusion}

These subgroups indicate that the target audiences of educational institutions in the Cape Metropolitan are divided according to their beliefs about the factors considered important regarding tertiary education, and are further divided in many ways according to the socioeconomic circumstances in which the subgroups find themselves.

This study also gives valuable information on the preference for sources of students who are planning to study further. The fact that not all subgroups depend on the same themes for sources, that is, media, direct sources and social sources, indicates that the IMC plan must be tailor-made to address the specific needs of each subgroup by means of a varied marketing communication mix.

The above data obtained from this study can be used to develop an IMC plan that can market to the five distinct segments that exist within the target market of tertiary institutions in the Cape Metropolitan. These five segments represent subgroups in the market place that have shown unique characteristics, thereby showing that unique communication messages in the relevant sources should be developed in order to maximise marketing impact.

What is significant about this study is that, although democracy has been in place for the majority of these young lives, the lines of socio-economic separation still exist in South Africa and continue to impact on how subgroups are formed. This holds a challenge for marketing communication specialists who need to take cognisance of these characteristics and customise messaging that will take the circumstances of such subgroups into consideration.

Youth from disadvantaged households still believe that access to university is unattainable, so set their targets lower at Technikon and college. The absence of role models in these communities (Ramphele, 2002) also heavily impacts on their decisions to 
study further. Marketing strategies would be well targeted at establishing how to break down the barriers to entry, and also how to create role models in these communities by means of marketing communication that could change mindsets.

It is clear from the study that the information needs of different subgroups remain varied. Information is not limited to only one type of need for the entire target market, but it is recognised that subgroups value certain types of information in order to make decisions about studying further. These needs seem to be impacted by the individual's socioeconomic circumstances, needs that the potential student wishes to meet, and career ambitions.

\section{Recommendation}

The types of sources that the members of different subgroups prefer to consult indicate that each subgroup has specific preferences and that these, too, are influenced by the individual's socio-economic circumstances. Within the media sources category, the use of specific media vehicles is also specific to each subgroup.

The study therefore shows that, for an institution to target the potential student target market as a whole within the Cape Metropolitan, it has to take cognisance of the different subgroups that exist, and tailor-make the content, presentation and media used according to the preferences of each.

The study shows that treating the target market as a single homogeneous market with one message to "fit all sizes" will not successfully reach the market or meet their individual needs.

Finally, as in an IMC approach, these individual messages and media need to be integrated and co-ordinated in the institution's overall marketing strategy.

\section{References}

Bruwer, J. (1996), "Marketing a public higher educational institution through targeted and market research on its freshmen applicants and enrolee pools", South African Journal of Higher Education, Vol. 10 No.2, pp.20-9.

Coetzee, J. (2006), “Eigen values”, available at: jcoetzee@hakuna.up.ac.za, .

Cooper, D.R., Schindler, P.S. (2006), Marketing Research, international ed., McGrawHill Irwin, Boston, MA, .

Cosser, M., Du Toit, J. (2002), From High School to Higher Education? Factors Affecting the Choices of Grade 12 Learners, Human Sciences Research Council Publishers, Cape Town, available at: www.hsrcpublishers.co.za (accessed 28 January 2005), . 
Davies, S., Guppy, N. (1997), "Fields of study, college selectivity, and student inequalities in higher education”, Social Forces, Vol. 75 No. 4, pp. 1417-38, available at: http://search.epnet.com (accessed 20 February 2005), .

Edelman, R. (2004), “The relationship imperative”, Journal of Integrated Communications, available at:

www.medill.northwestern.edu/imc/studentwork/pubs/jic.htm (accessed 6 March 2005), .

Gaika, N.G. (2002), “The development of effective promotional strategies to market public further education and training colleges in the Eastern Cape Province”, unpublished master's thesis, University of Port Elizabeth, Port Elizabeth, .

Goff, B., Patino, V., Jackson, G. (2004), "Preferred information sources of high school students for community colleges and universities", Community College Journal of Research and Practice, Vol. 28 pp.795-803.

Imenda, S.N., Kongolo, M. (2002), "Sustained student enrolments at a historically white South African university: a case study of Rhodes University”, Journal of Higher Education Policy and Management, Vol. 24 No. 2, pp. 219-30, available at http://search.epnet.com (accessed 20 February 2005), .

Mouton, J. (2004), How to Succeed in Your Master's and Doctoral Studies: A South African Guide and Resource Book, Van Schaik Publishers, Pretoria, .

Municipal Demarcation Board (2006), Municipal Demarcation Board, available at: www.demarcation.org.za (accessed 16 July 2006), .

Mzimela, L. (2002), Marketing in Higher Education - It's a Multitude of Missed Opportunities, available at: www.biz-community.com/article/196/98/346.html (accessed 10 September 2005, .

Nunnally, J.C. (1967), cited in Churchill, G.A. Jr, “A paradigm for developing better measures of marketing constructs”, Journal of Marketing Research, Vol. 16, February, 1997, pp. 64-73, .

Ramphele, M. (2002), Steering by the Stars: Being Young in South Africa, Tafelberg, Cape Town, .

Smith, A.M. (1999), "Some problems when adopting Churchill's paradigm for the development of service quality measurement scales", Journal of Business Research, Vol. 46 pp.109-20.

\section{Further Reading}

AsgiSA (2006), “Accelerated and shared growth initiative for South Africa”, available at: www.info.gov.za/asgisa/asgisa.htm/ (accessed 16 July 2006), . 
James, R. (2002), “How student perspectives challenge conventional marketing theory”, paper prepared for Conference on Strategic Marketing for Education, Sydney, 15-16 April, .

Manuel, T. (2005), Budget Speech 2005, Trevor Manuel, 23 February 2005, available at: www.info.gov.za/speeches/2005/05022316151001.htm (accessed 7 March 2005), .

Pandor, N. (2005), address by Minister of Education, Naledi Pandor, at the Unisa brand launch, available at: www.unisa.ac.za (accessed 16 July 2006), .

South Africa. Department of Education (1998), Green Paper on Further Education and Training, available at: www.polity.org.za/html /govdocs/green_papers/furtheredgp1.html (accessed 5 March 2005), .

Statistics South Africa (2001), Person Statistics Municipality Level, 2001, Statistics South Africa, Pretoria, .

Study South Africa (n.d.), Born Free and Colour Blind, available at: www.studysa.co.za/studysa3.htm accessed 20 February 2005), .

\section{Corresponding authors}

J. Bonnema can be contacted at: jeanne@myisp.co.za and D.L.R. Van der Waldt can be contacted at: delarey.vanderwaldt@up.ac.za 